\title{
HISĀB IKHTIBĀR AL-LUGHAH AL-'ARABIYYAH 'ALĀ AL-MUSTAWA AL WATHANY LI L-MADĀRIS AS-TSĀNAWIYYAH AL-ISLĀMIYYAH Fī INDONESIĀ
}

\section{Raswan}

Universitas Islam Negeri (UIN) Syarif Hidayatullah Jakarta Jl. Ir. H. Juanda No.95, Ciputat, Kota Tangerang Selatan, Banten, Indonesia 15412

Email: raswan@uinjkt.ac.id

Received; January 2017; accepted June 2017; published June 2017

\begin{abstract}
This paper aims to uncover tests quality on the National Standard Madrasah Final Examination academic year 2012/2013 on the level of Madrasah Aliyah in Indonesia. Quality means qualitative and quantitative term. Qualitative analysis is done by critical reading, doing discussions and making manual form of multiple choice questions in Arabic. The study concluded that the quality of a qualitative test is still very low, many mistakes in making questions are found, such as writing numbers in arabic, and spreading the correct answer is not balanced. From the aspect of test coverage, in National Standard Madrasah Final Examination, there is no problem with regarding the listening comprehension and many questions that are not contextualized with the actual context of the Arabic language.
\end{abstract}

Keywords: Qualitative, Quantitative, Validity, Test, National Level.

حساب اختبار اللغة العبية على المستوى الوطني للمدارس الثانوية الإسالامية في إندونيسيا ملخص البحث

$$
\begin{aligned}
& \text { يهدف هذا البحث إلى الكشف عن نوعية الاختبار النهائي على المستوى الوطني للسنة الدراسية r ا • r/ ا • بم للمدارس } \\
& \text { الثانوية الإسلامية في إندونيسيا. والمراد بالنوعية هنا جودة أسئلة الاختبار من حيث كميتها ونوعيتها. وطريقة التقويم في هذا } \\
& \text { البحث هي طريقة كيفية بقيام المناقشة والملاحظة العميقة والنقدية حول الأسئلة في الاختبار النهائي على المستوى الوطني في }
\end{aligned}
$$

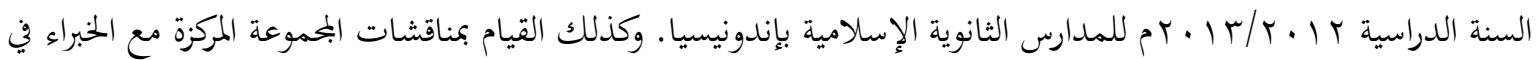

$$
\begin{aligned}
& \text { تقويم اللغة العربية وأيضا مع مدرسي اللغة العربية للمدارس الإسالامية وخاصة هم الذين تخرجوا في قسم اللغة العربية لكوهم } \\
& \text { مستوعبين على تقويم الاختبارات الجيدة وغير الجيدة. و نتائج البحث هي أنه من ناحية مستوى نوعية الاختبار كيفيا مـازال } \\
& \text { في الاختبار نقصان وأخطاء وهي في كتابة الأرقام التي ما زالت مكتوبة بطريقة خاطئة، وأيضا في توازن الخيار الصحيح بين } \\
& \text { الخيارات البديلة. ومن ناحية توفير الاختبار العناصر الواجبة في اختبار اللغة العربية. } \\
& \text { المصطلحات الرئيسية: نوعية ، كيفية، صدق، اختبار، المستوى الوطني }
\end{aligned}
$$


اختبار المدرسة هو عملية قياس إبحاز كفاءة التلاميذ الذي قامت به المدرسة للحصول على اعتراف الإبحازات وهو

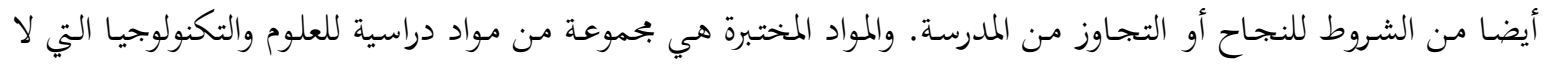

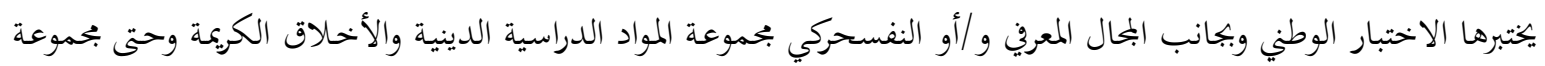
مواد دراسية الجنسية والشخصية التي سوف يتم التعيين في بحال اختبار المدرسة. وأما الاختبار الوطني فهو عملية قياس لإنحاز كفـاءة التلاميذ في بعض المواد الدراسية المعينة في بحموعة المواد الدراسية للعلوم والتكنولوجيا مـن أجلـ تقييم إبحاز المعايير الوطنية للتعليم (Kemenag, 2007, p. 2). وأما الاختبار النهائي للمدرسة الإسلامية على المستوى الوطني فهو الذي قامت به المدرسة أو الوزارة للشؤون الدينية في فاية العملية التدريسية في المدرسة لقياس إبحاز كفاءة التلاميذ حسب معايير الكفاءة حول المواد الدينية الإسلامية ومادة اللغة العربية. ولذذا الاختبار أهداف وهي قياس إبحاز مخرجات تعلم التلاميذ في فاية مراحل المدرسة حسب لمبل معايير

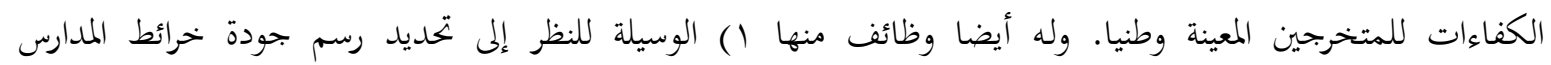

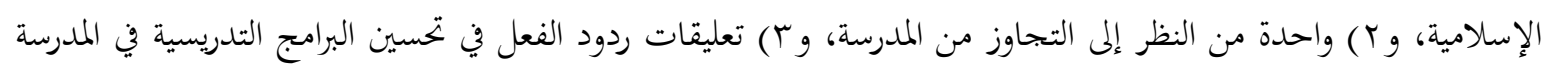

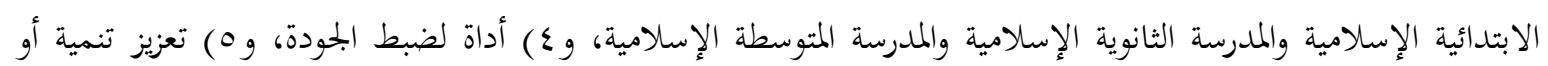

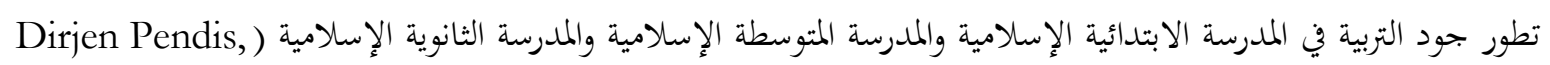
.(2013, p. 1 وعرفنا أنّ للاختبارات أهمّية كبيرة في تحصيل التدريس. ولكن لابد أن تكون الاختبارات جيّدة حيث تستطيع على

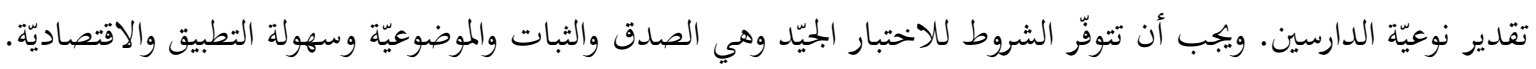

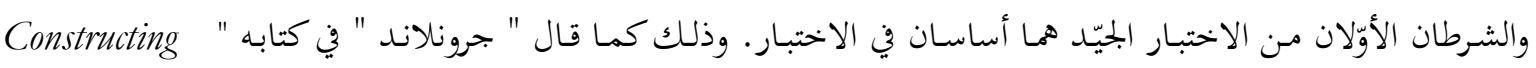

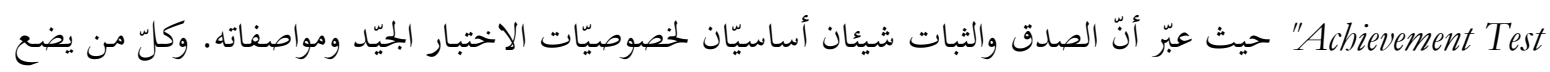
الاختبار ويصنعه لا بد لهم معرفة الثبات والصدق ومعرفة مراحل إجرائهما (Gronlund, 1996, p.105).

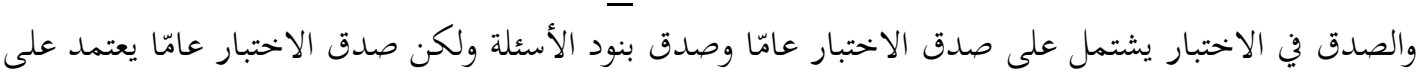

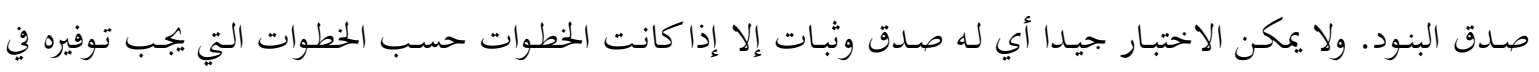

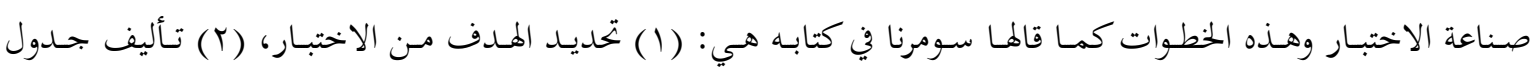

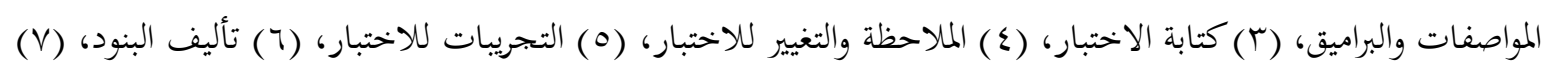

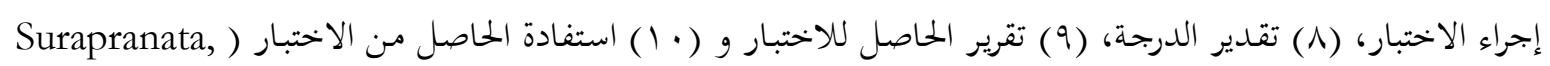
.(2005, p. 45

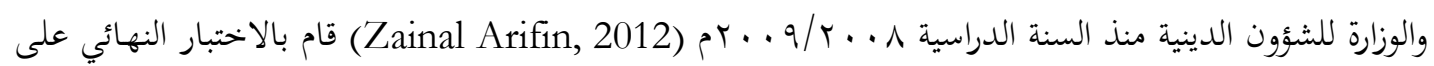

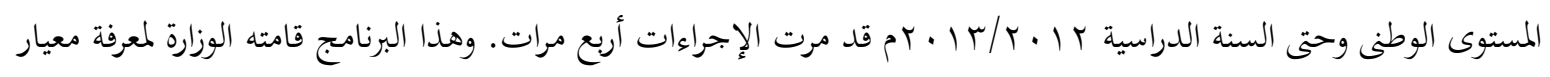

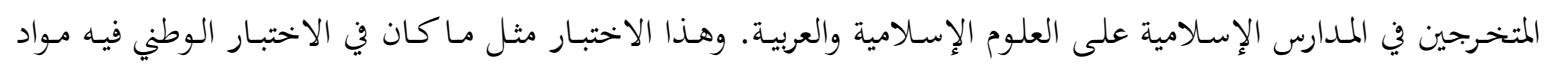

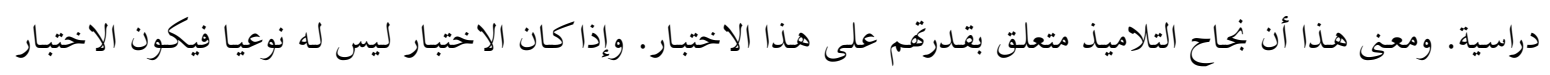

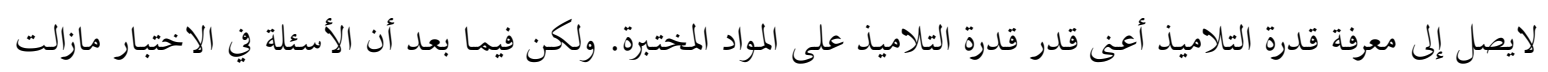

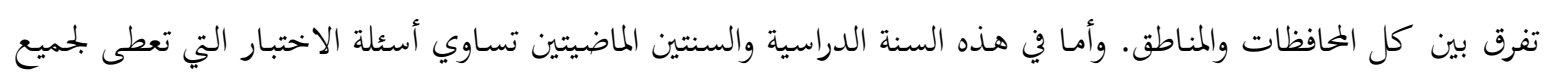


المدارس في إندونيسيا بينما كانت الوزارة للشؤون الدينية في المنطقة أو المحافظة ليست إلا تضعيف أو تصوير ذلك الاختبار أو تلك الأسئلة. وأهم غرض من هذا البحث معرفة مستوى نوعية الاختبار كيفيا.

طريقة البحث

طريقة التقويم عامة تنقسم إلى ثلاثة وهي طريقة كمية وطريقة نوعية أوكيفية وطريقة انتقائية بين كمية نوعية. فالطريقة

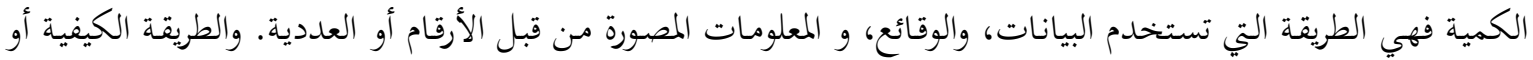

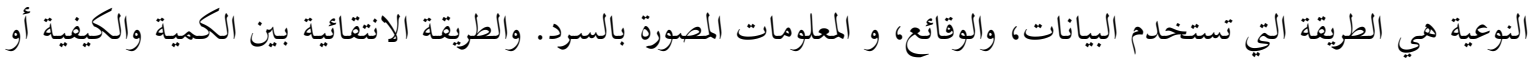

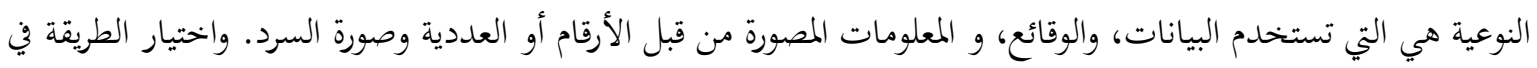

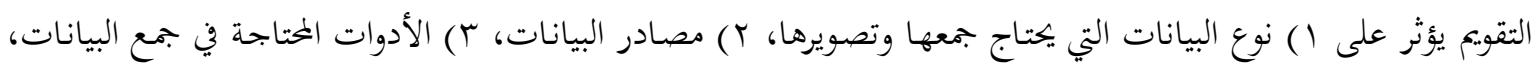

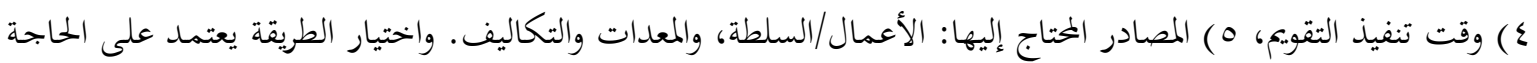
الحقيقية والواقعية. وطريقة التقويم في هذا البحث هي طريقة كيفية بقيام المناقشة والملاحظة العميقة والنقدية حول الأسئلة في

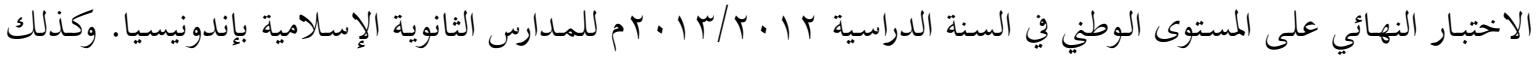

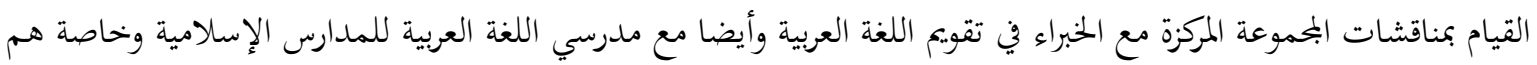
الذين تخرجوا في قسم اللغة العربية لكوفم مستوعبين على تقويم الاختبارات الجيدة وغير الجيدة.

معنى النموذج على حد قول تشاو Y. R. Choa إطار مرجعي، وصف لشيء ما، نظير أو شبيه، منهج مقترح

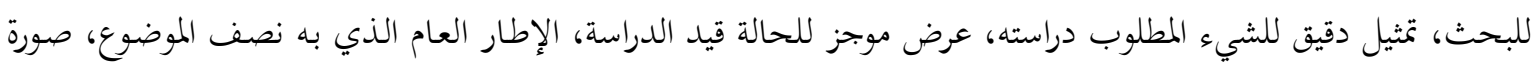

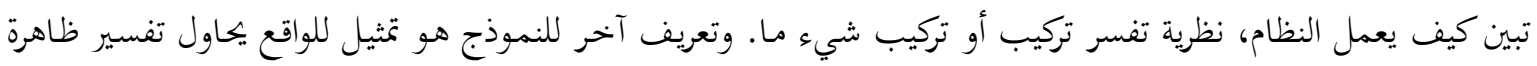

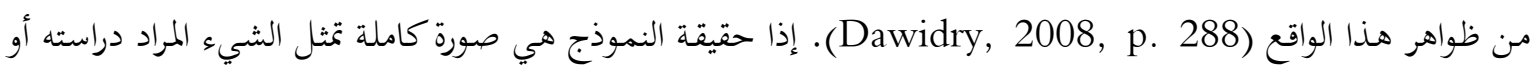
بيانه. وأما نموذج التقويم فهو تصور نظري للخطوات اللازمة للتوصل إلى قرار معين بشأن الشيء المراد تقويمه وتقرير ذلك للمعنيين (Drandry, 2006, p. 9). ونموذج التقويم هو التقويم عن كيفية التصميم وأدائه، وكثير من الوقوع أن رعاية التقويم يطلب أن يكون البرنامج مقوما بالنموذج الخاص (Wirawan, 2008, 22). التعريف الثاني أحسن وأشمل من الأول ويمكن

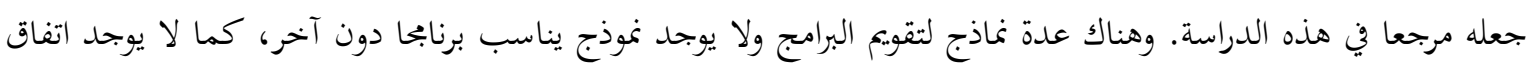

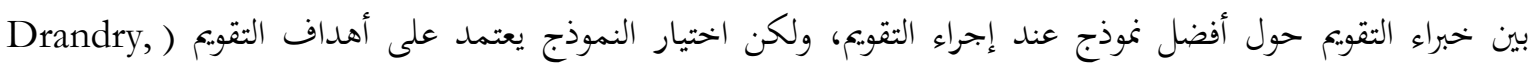
.(2006, p. 17

وفي تطبيق التقويم يمكنا اختيار النموذج الأكثر تناسبا لموضوع البحث لأنه ليس هناك نموذج أحسن من غيره.

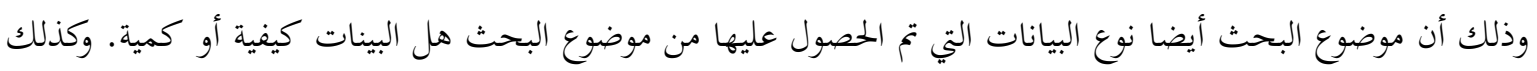

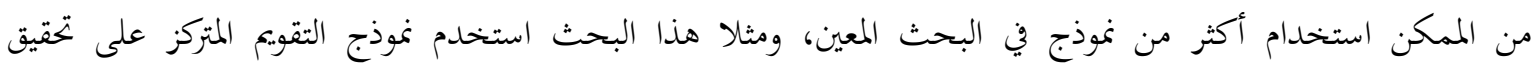

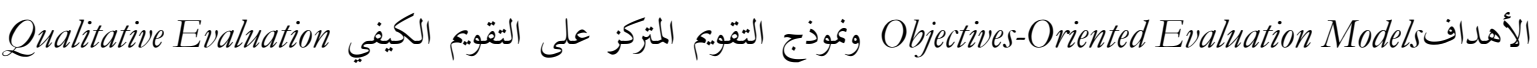


Models. لأن البيانات المتحصل عليها حول البيانات الكيفية والكمية، البينات الكيفية هي حول بنود الأسئلة للاختبار

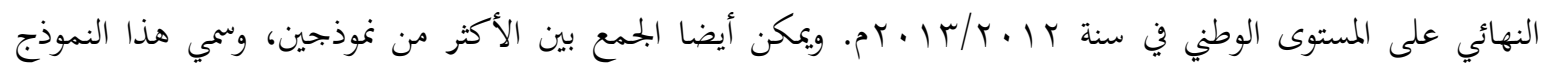
بالنموذج التوليفي أو الانتقائي.

\section{مواصفات الاختبار الجيد}

إن للاختبار الجيد ثلاثة معايير وهي الصدق والثبات وعدم التدبدب في التقويم. والمراد بالثبات هو يمثل الاتساق مع التقييم الإجرائي في قياس ما والمراد بالصدق هو انعكاس الاختبارات على الاعتمادية من الأعلى على أساس الدرجة ونسيد ومبني

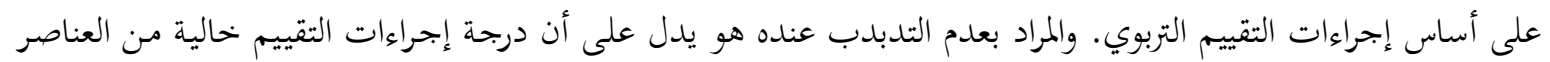

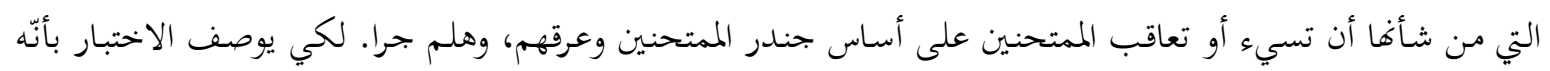

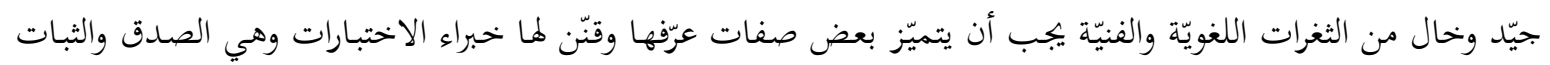

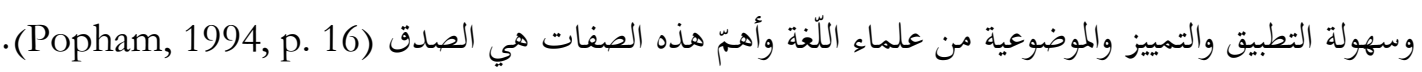

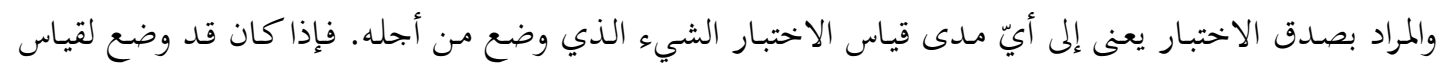
حصيلة الدارس في المفردات فهل يقوم بقياس هذا العنصر حقّا أم أنّه يقيس عنصرا آخر مثل التراكيب أو الأصوات أو أو غيرها.

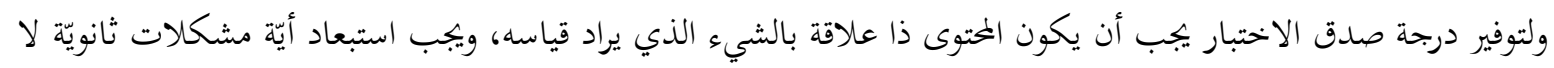
علاقة لها به.

\section{صدق المحتوى}

صدق المحتوى بمعنى في المقام الأوّل بما يجب أن يتضمّنه الاختبار . وما يتضمّنه الاختبار يعتمد على تحليل جيّد للّغة

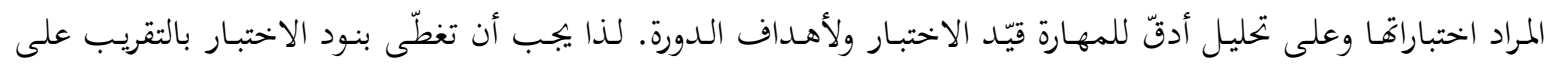

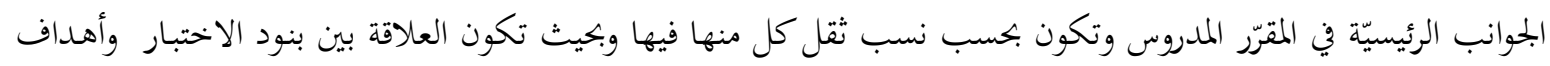

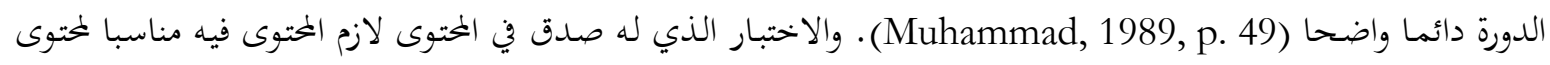
المناهج الدراسية التي تم تدريسها المدرسون. وكان المحتوى وكيل لعينة نتيجة التدريس التي يجب إبلاغها حسب أليأ أهداف المناهج

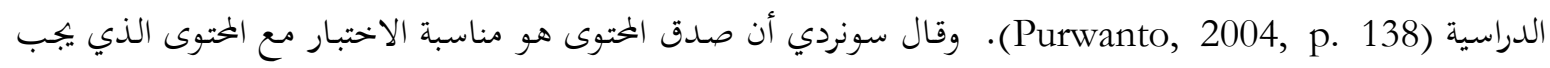

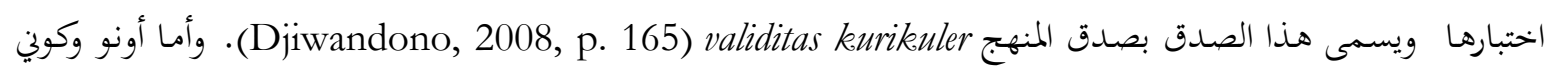
عبر أن الصدق الظاهري هو قدرة الاختبار على قياس المفاهيم التي كانت في المحتوى الذي يريد قياسها، كمثل قدرة تقييم

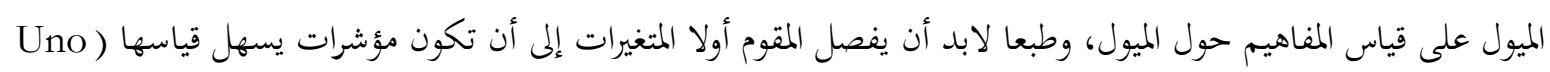
.(and Koni, 2012, p. 152 وأما يونس والشيخ عبر أن صدق المحتوى هو عرض المقياس على بحموعة من المحكمين المتخصصين في بحال تعليم

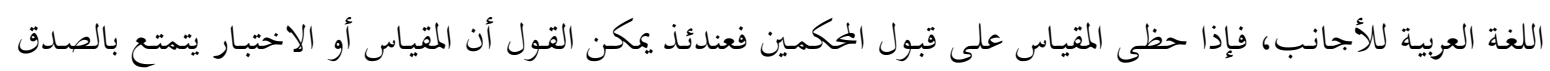

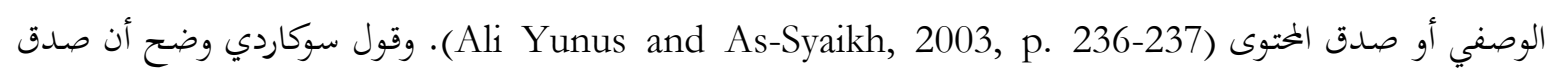

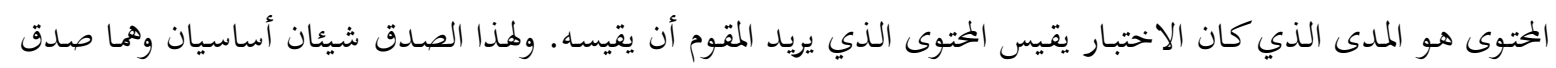


المحتوى وصدق العينة من المحتوى. والأول منهما هو قدرة الاختبار على تصوير شمولية المواد التي سوف يقومها المقوم، والثاني

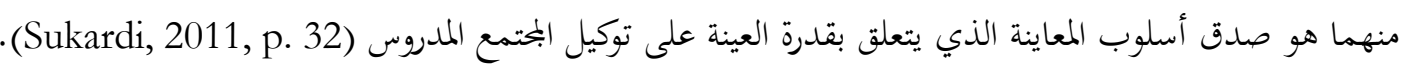

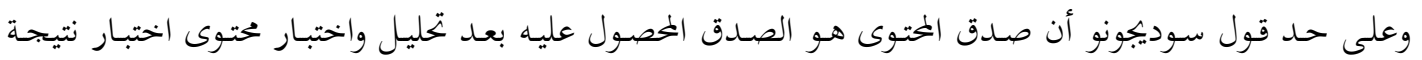
التدريس، والمختوى يصور جميع مواد التدريس الذي يجب تدريسه (Sujana, 2009, p.164). والهدف من هذا الصدق هو لمعرفة مدى سيطرة التلاميذ على مواد تم تدريسها وتغيرات نفسية لدى التلاميذ بعد خطوات التدريس المعين وهناك اسم آخر لهذا الصدق وهو الصدق المنهجي أوالصدق التصميمي التعابيري والصدق المنطقي المعقول (Arifin, 2012, p. 248-249).

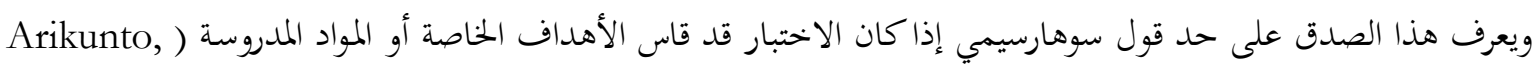

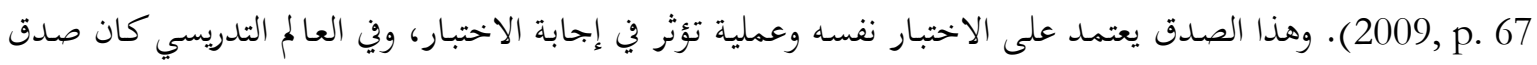

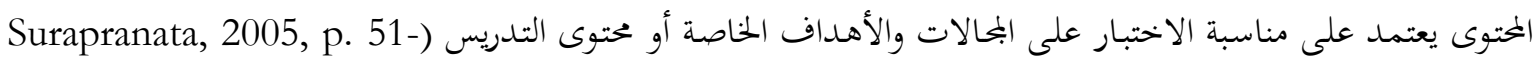

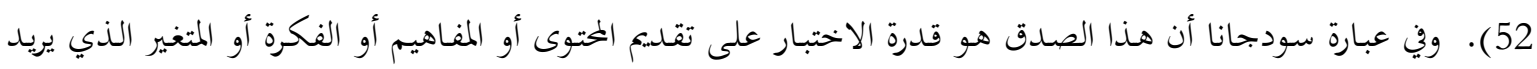
قياسها (Sudjana, 2009, p. 13). وقول أونو وكوني وضح أن صدق المحتوى هو قدرة الاختبار على شمولية العينة الشاملة

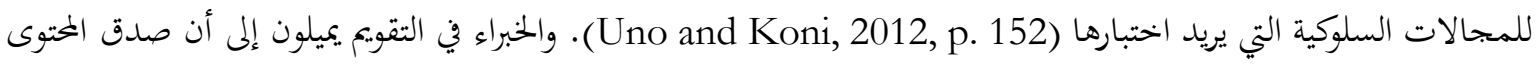

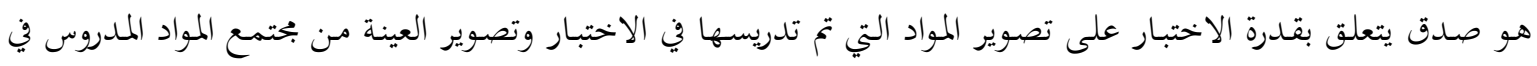

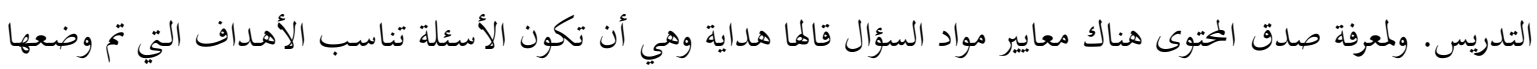

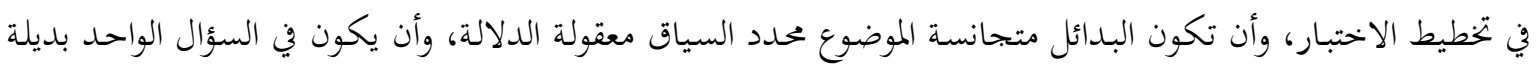

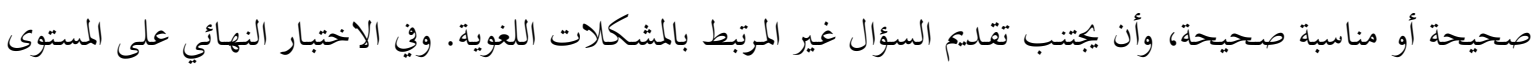

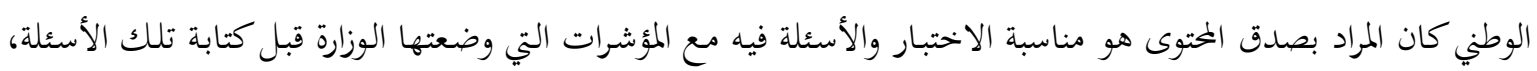

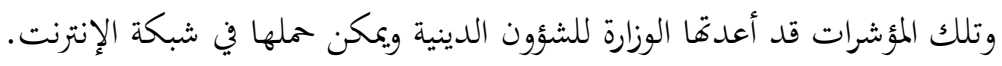

\section{صدق المحتوى للاختبار الموضوعيّ من نوع الاختيار من متعدد}

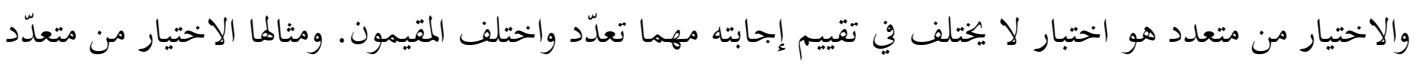

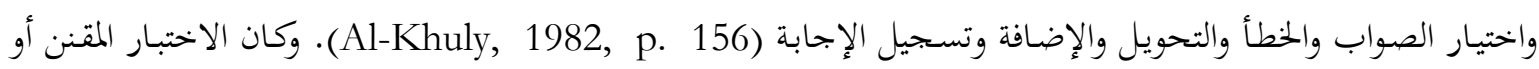
الموحد مثل الاختبار النهائي على المستوى الوطني يستعمل الاختبار الموضوعي وخاصة الاختيار من متعدد. وهذا النول النوع من

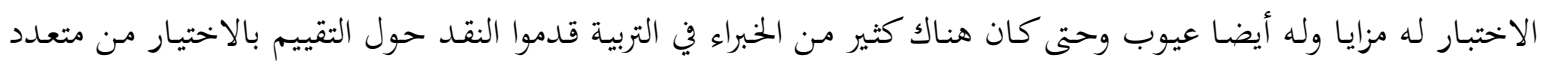

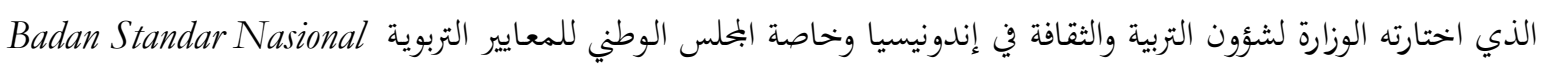
Arifin, 2012, p. 50) Pendidikan Indonesia/BSNP والتجاري وأيضا في الاختبارات النفسية (Athanasao and Lamprinaou, 2002, p. 127).

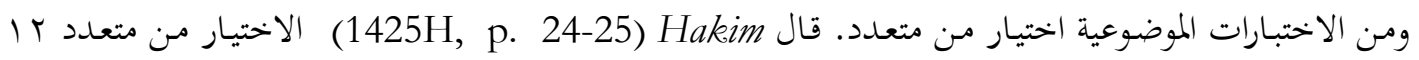

إرشادة تالية لوضعه:

$$
\begin{aligned}
& \text { - - اختيار صيغة السؤال بعناية: ومن ذلك. } \\
& \text { - ترتيب الخيارات رأسياً وعم كتابتها على السطر الواحد. } \\
& \text { - - تنسيق الخيارات منطقياً ونخوياً مع المقدمة. }
\end{aligned}
$$




$$
\begin{aligned}
& \text { - - تطرح المقدمة مسألة كاملة، أو مفهوماً متكاملاً قبل الانتقال للخيارات. }
\end{aligned}
$$

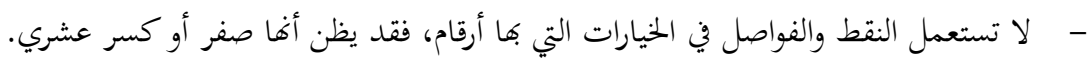

$$
\begin{aligned}
& \text { - ل ليس من الضروري تساوي عدد الخيارات في جميع الأسئلة. }
\end{aligned}
$$

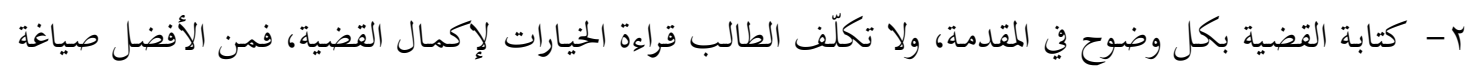

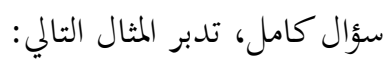

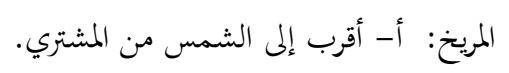

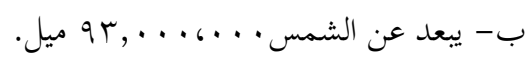

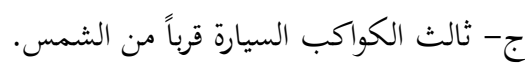

هذا السؤال من نوع أسئلة الصواب والخطأ، لأن المقدمة قصرت عن عرض المبارة المسألة كاملة.

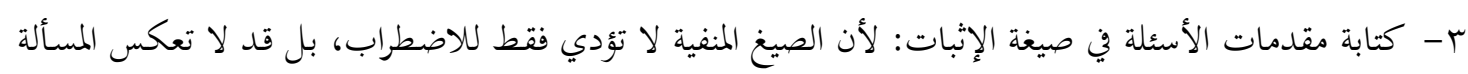

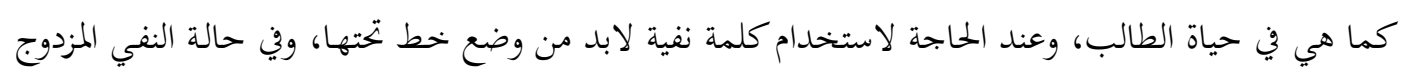
فيجب التخلص منهما تماماً.

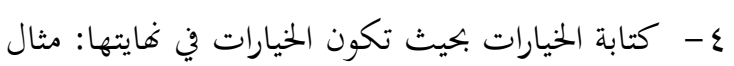

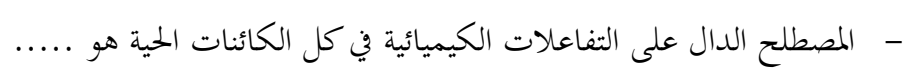

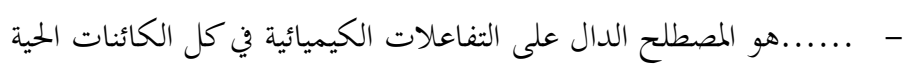

$$
\text { ه- الإيجاز توفيراً لوقت الاختبار الثمين. }
$$

ج- الإبداع : أي استغلال ميزة تعدد الإمكانات التي تقيس بها أسئلة الاختيار المتعدد النتائج التعليمية المهمة، وحاول

$$
\text { بلوغ هذا الهدف بجعل نصف الأسئلة فوق مستوى التذكر. }
$$

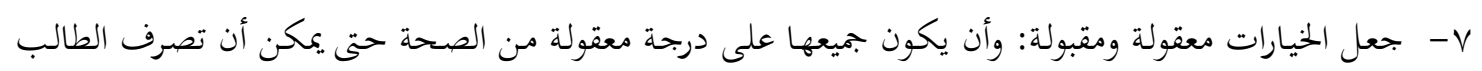

$$
\text { غبر المتمكن. }
$$

$$
\text { - م- التأكد مع عدم وجود أكثر من إجابة صحيحة. }
$$

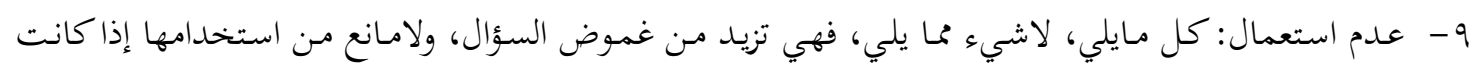

$$
\text { • الإلإبتعاد عن التكرار غير الضروري. }
$$

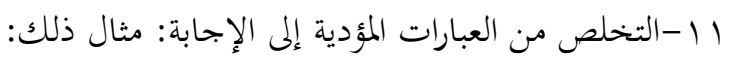

$$
\text { أ- أن أن يكون الخيار الصحيح أطول من غيره. }
$$

ب- وجود كلمات متكررة أو مثيلاتما في المقدمة وفي غيره الخيارات.

$$
\begin{aligned}
& \text { ج- وجود تركيبات نحوية دالة على الإجابة. } \\
& \text { د- تفضيل خيار محدد. }
\end{aligned}
$$

هـ - وجود محددات في المقدمة ويف أحد الخيارات.

r ا-ترتيب الخيارات: إن ترتيب الخيارات المختملة في تسلسل منطقي يساعد الطلبة على تحديد المديد الخيارات، حيث ترتب

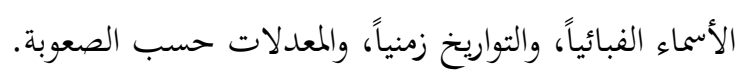

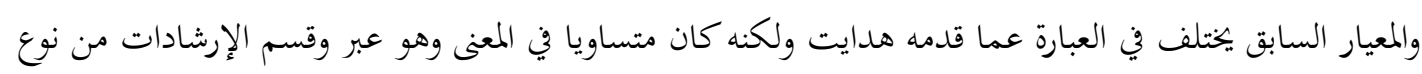




$$
\begin{aligned}
& \text { الاختيار من متعدد إلى ثلاثة كبير كما في التالي: }
\end{aligned}
$$

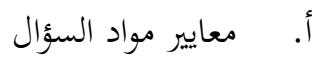

- - أن تكون الأسئلة تناسب الأهداف التي تم وضعها في تخطيط الاختبار - أن تكون البدائل متجانسة الموضوع محددة السياق معقولة الدلالة النالة -

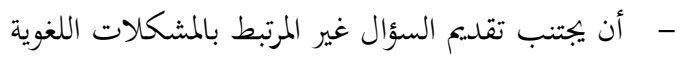
ب. بائمعايير التركيبية للأسئلة

- أن يكون السؤال واضحا ومحددا بحيث لايؤدي إلى الغموض وتعدد المعنى.

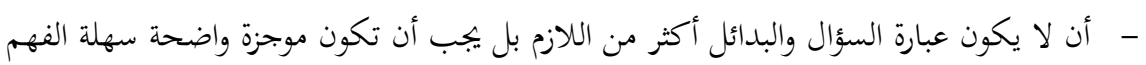

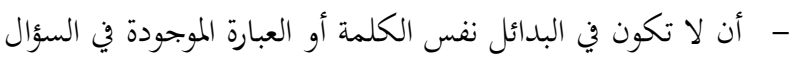

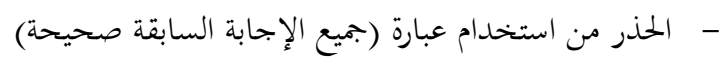

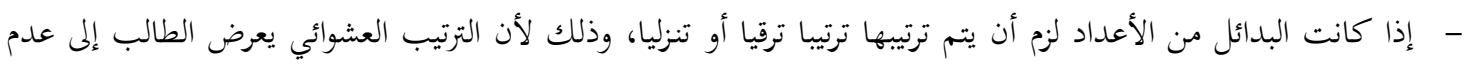
التركيز - الحذر من استخدام العبارات غير المحددة مثل أكثرها، أحيانا، غالبا، تقريبا، الأحسن أظن.

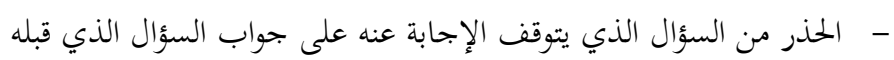

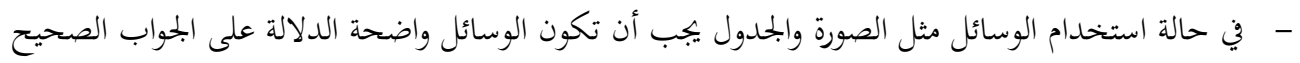
- - الحذر من تكرار كلمة أو أكثر في البدائل

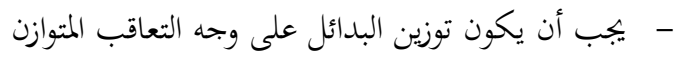
ج. معايير التعبير اللغوي - - يلزم في الاختبار استخدام عبارات صحيحة في كتابة الحروف وفي المباني الصرفية وفي التراكيب النحوية وفي الإعراب كما

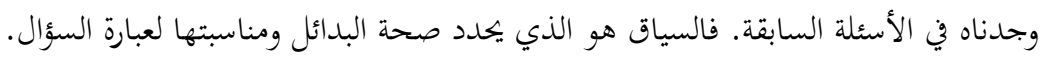

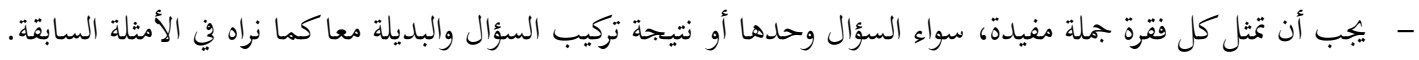
- - وفي حالة الاختبار الشفوي مثل اختبار الاستماع لابد أن يكون عبارة السؤال جملة كاملة.

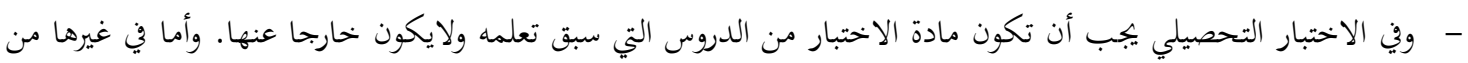
الاختبارات فيتحدد مستوى الأسئلة سهولة وصعوبة على حسب مقتضى الجهات المعنية."

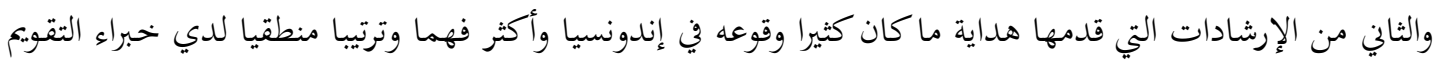

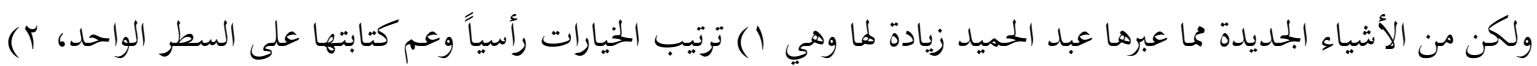

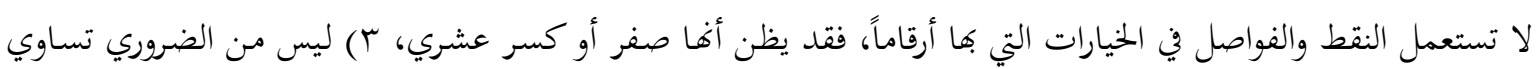

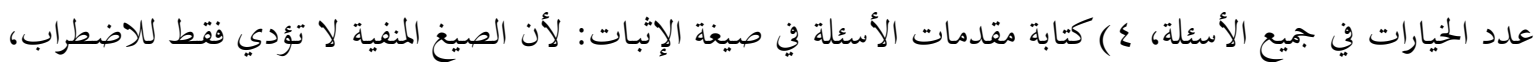

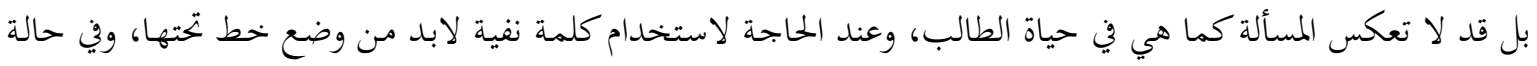

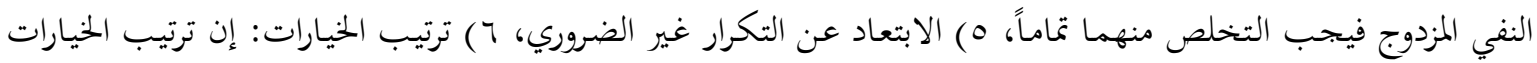

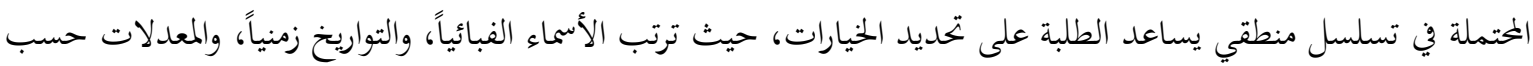

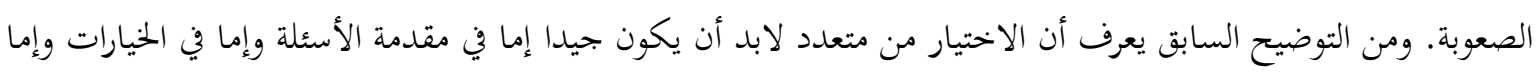


في اللغة التي استخدمتها مقدمة الأسئلة والخيارات حيث تكون منطقية ودالة على معنى مفيد والحذر من الكلمات غير المفيدة وغير ذلك. وإذا ما أحسن تصميمها وبناؤها فكان الاختيار من معتدد اختبارا جيدا.

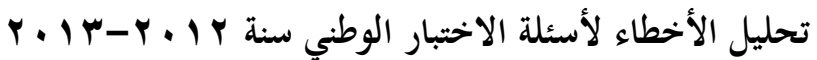

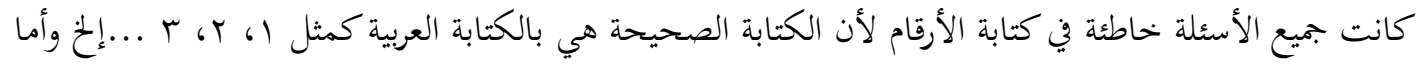

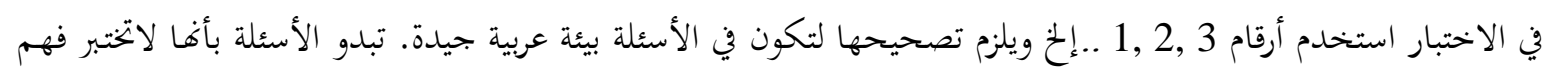

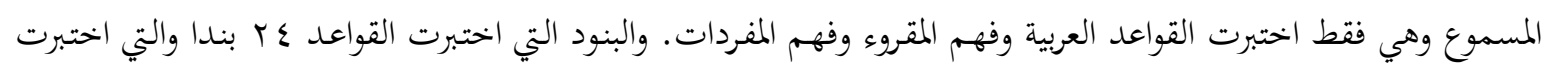

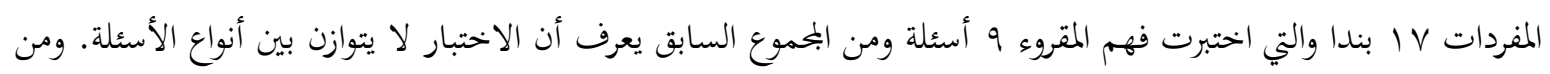

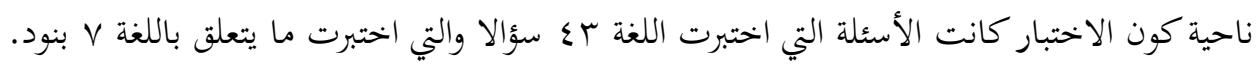

$$
\text { هذه من البنود التي اختبرت القواعد العربية: }
$$

\begin{tabular}{|c|c|c|c|}
\hline السؤال الحققة & نوع الأخطاء & السؤال الخناطئ & 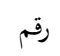 \\
\hline |قرأ الفقرة جيدا! & - - البدائل غير متجانسة & \multicolumn{2}{|l|}{ |قرأ الفقرة جيدا! } \\
\hline انظر إلى المريض، هو يشكو بالم & - البديلة الصحيحة أكثر من واحدة & \multicolumn{2}{|l|}{ انظر إلى المريض، هو } \\
\hline شديد، عنده ألم شديد في رأسه وفي & - - السؤال غير محدد & \multicolumn{2}{|l|}{ يشكو بالم شديد، عنده ألم } \\
\hline معلتي. ويشعر بهذا الألم منذ ثلاثة أيام، & - عبارة السؤال والبدائل أكثر من اللازم & \multicolumn{2}{|l|}{ شديد في رأسه وفي معدني. } \\
\hline وقد تناول بعض الأقراص ولم تنفع. فذهب & - ت تكرار كلمة في البدائل & \multicolumn{2}{|l|}{ ويشعر بهذا الألم منذ ثلاثة أيام، } \\
\hline إلى عيادة الطبيب. & - ت توزيع البدائل غير التعاقب والمتوازن & \multicolumn{2}{|l|}{ وقد تناول بعض الأقراص ولم } \\
\hline الفعل المضارع في الفقرة السابقة هو .... & - - الفقرة ليست جملة مفيدة & \multicolumn{2}{|l|}{ تنفع. فذهب إلى عيادة الطبيب. } \\
\hline أ- يشكو & & \multicolumn{2}{|l|}{ الفعلان المضارعان في الفقرة } \\
\hline ب- ذهب & & \multicolumn{2}{|l|}{ السابقة ! } \\
\hline ج- تناولَ & & أ- يشكو - انظر & \\
\hline د- دانظر & & ب- ذهب - تناولَ & \\
\hline \multirow[t]{3}{*}{ هـ- - عيادة } & & ج- عيادة - يشكو & \\
\hline & & د- شديد - يشعر & \\
\hline & & هـ- تشعر - تنفع & \\
\hline
\end{tabular}

\begin{tabular}{|c|c|c|c|c|}
\hline 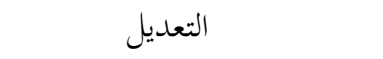 & التحليلات/الاقتراحات & & السؤال للامحان & 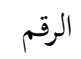 \\
\hline تقرأ الطالبة المحلات الإسلامية في & البدائل غير متجانسة في & - & تقرأ الطالبة المحلات & 1 \\
\hline$\ldots$ & صورة اللفظ & & الإسلامية في .... & \\
\hline أ. أل الحديقة & & & أ. المقصف & \\
\hline ب. القاعة & & & ب. القاعة & \\
\hline ج. الإدارة & & & ج. الملعب & \\
\hline د. المكتبة & & & د. المكتبة & \\
\hline هـ. الغرفة & & & هـ. المعمل & \\
\hline
\end{tabular}




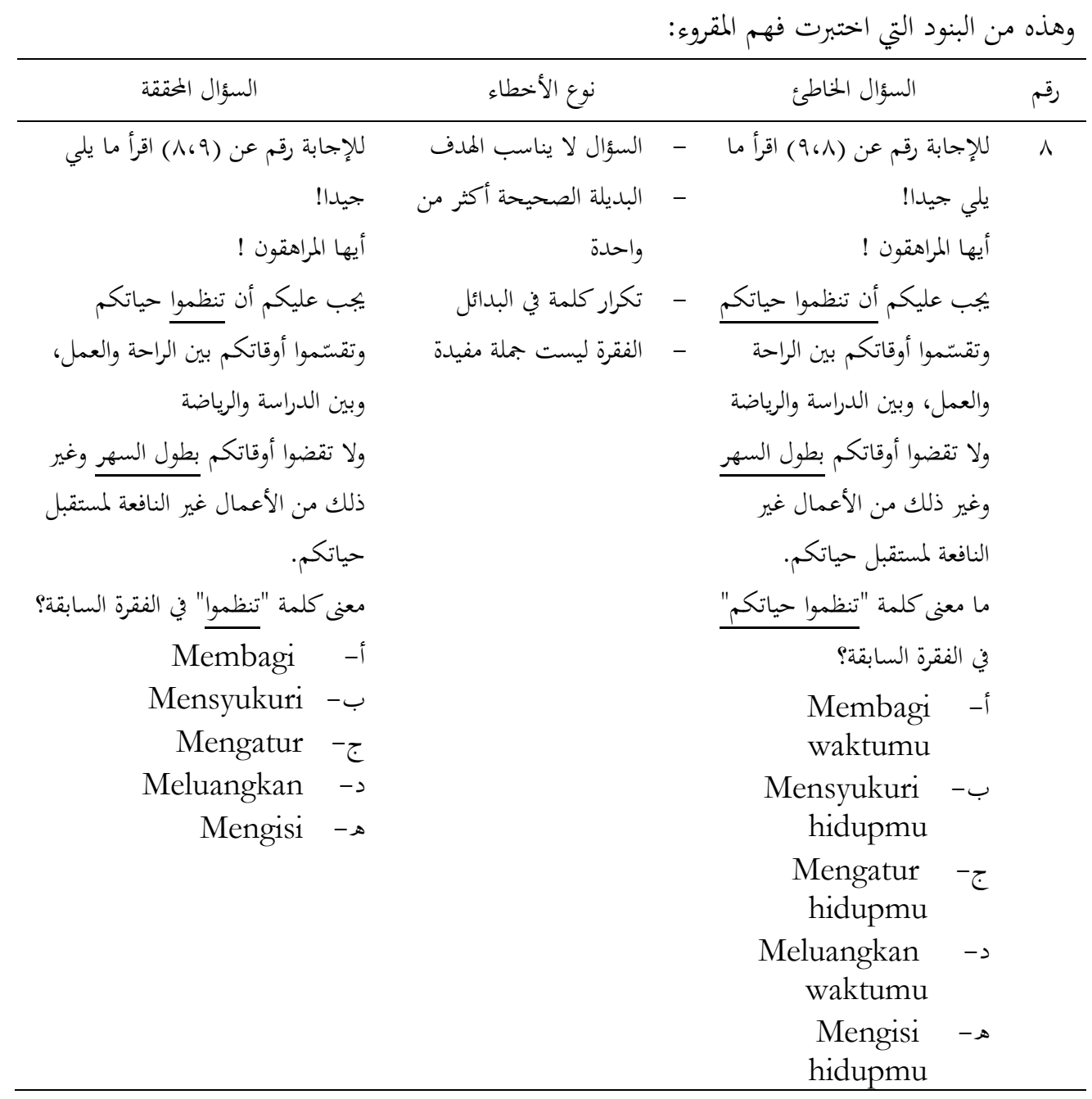

والأمثلة السابقة تدل أيضا أن المثال الأول مما يختبر ما يتعلق باللغة وأما الثاني والثالث فما يختبر اللغة حقيقيا. لأن حقيقة النحو هو ما يتعلق باللغة إذا كان السؤال مثل ما سبق، وأما السؤال الصحيح للقواعد هو سؤال يختبر حول صحة الجملة باستخدام القواعد المحددة.

بعد القيام بالتحليل التقويمي، توجد في أسئلة الاحتبار الوطني الأخطاء كما الآتية: ( ) البدائل في الخيارات البديلة غير متجانسة في صورة اللفظ

\begin{tabular}{|c|c|c|c|c|c|}
\hline السؤال المققة & نوع الأخطاء & & \multicolumn{2}{|l|}{ السؤال الخاطئ } & رقم \\
\hline أ الطالبة المحلات الإسلامية في .... & البدائل غير متجانسة في & - & \multicolumn{2}{|c|}{ تقرأ الطالبة المحلات الإسلامية } & 1 \\
\hline . . الحديقة & صورة اللفظ & & \multicolumn{3}{|c|}{ في .... } \\
\hline ب. الق القاعة & & & \multicolumn{3}{|c|}{ أ. المقصف } \\
\hline 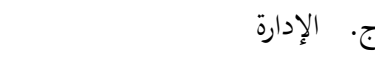 & & & \multicolumn{3}{|c|}{ ب. القاعة } \\
\hline 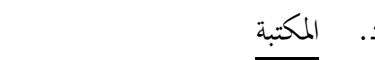 & & & \multicolumn{3}{|l|}{ 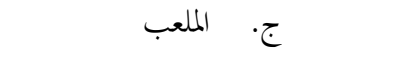 } \\
\hline ئ. الغرفة & & & \multicolumn{3}{|l|}{ 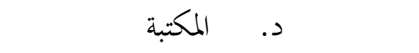 } \\
\hline & & & \multicolumn{3}{|c|}{ هـ. } \\
\hline
\end{tabular}


الخطأ في هذا السوال يبدو أن البدائل في الخيارات البديلة غير متجانسة في صورة اللفظ. Y) البدائل غير متجانسة في صورة اللفظ وطوله

\begin{tabular}{|c|c|c|c|c|c|c|}
\hline \multicolumn{2}{|l|}{ السؤال المحققة } & \multicolumn{2}{|l|}{ نوع الأخطاء } & \multicolumn{2}{|l|}{ السؤال الخاطئ } & \multirow{2}{*}{ رقم } \\
\hline الطلاب والطالبات في & يدرس & البدائل غير & - & الطلاب والطالبات & يدرس & \\
\hline & $\ldots$ & متجانسة في صورة & & & في ... & \\
\hline الفصل & أ- - & اللفظ وطوله. & & الفصل & 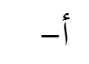 & \\
\hline المقصف & ب & & & الإدارة & ب & \\
\hline الملعب & ج- & & & الهيئة التدريس & ج- & \\
\hline المعمل & -2 & & & الغرفة المدير & -2 & \\
\hline المرحاض & $-\infty$ & & & المرحاض & $-\infty$ & \\
\hline
\end{tabular}

الخطأ في هذا السوال يبدو أن البدائل في الخيارات البديلة غير متجانسة في صورة اللفظ وطوله. r) السؤال لا يناسب الهدف

\begin{tabular}{|c|c|c|c|c|c|}
\hline السؤال المحققة & نوع الأخطاء & & \multicolumn{2}{|l|}{ السؤال الخاطئ } & رقم \\
\hline للإجحابة رقم عن (^،9) اقرأ ما يلي & السؤال لا يناسب & - & \multicolumn{2}{|c|}{ للإجحابة رقم عن (^،9) اقرأ ما يلي } & $\wedge$ \\
\hline 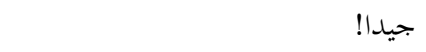 & الهدف & & \multicolumn{3}{|c|}{ 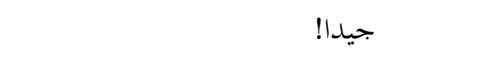 } \\
\hline أيها المراهقون ! & البديلة الصحيحة & - & \multicolumn{3}{|c|}{ أيها المراهقون ! } \\
\hline يجب عليكم أن تنظموا حياتكم & أكثر من واحدة & & \multicolumn{3}{|c|}{ يجب عليكم أن تنظموا حياتكم } \\
\hline وتقسّموا أوقاتكم بين الراحة والعمل، & تكرار كلمة في البدائل & - & \multicolumn{3}{|c|}{ وتقسّموا أوقاتكم بين الراحة } \\
\hline وبين الدراسة والرياضة & الفقرة ليست جملة & - & \multicolumn{3}{|c|}{ والعمل، وبين الدراسة والرياضة } \\
\hline ولا تقضوا أوقاتكم بطول السهر وغير & مفيدة ل & & \multicolumn{3}{|c|}{ ولا تقضوا أوقاتكم بطول السهر } \\
\hline ذلك من الأعمال غير النافعة لمستقبل & & & \multicolumn{3}{|c|}{ وغير ذلك من الأعمال غير النافعة } \\
\hline حياتكم. & & & \multicolumn{3}{|c|}{ لمستقبل حياتكم. } \\
\hline معنى كلمة "تنظموا" في الفقرة السابقة؟ & & & \multicolumn{3}{|c|}{ ما معنى كلمة "تنظموا حياتكم" في } \\
\hline Membagi & & & \multicolumn{3}{|c|}{ الفقرة السابقة؟ } \\
\hline Mensyukuri - & & & \multirow{2}{*}{$\begin{array}{c}\text { Membagi } \\
\text { waktumu }\end{array}$} & & \\
\hline Mengatur & & & & & \\
\hline Meluangkan & & & \multirow{2}{*}{$\begin{array}{r}\text { Mensyukuri } \\
\text { hidupmu }\end{array}$} & \multirow[t]{2}{*}{ ب- } & \\
\hline \multirow[t]{4}{*}{ Mengisi } & & & & & \\
\hline & & & $\frac{\text { Mengatur }}{\underline{\text { hidupmu }}}$ & ج- & \\
\hline & & & $\begin{array}{l}\text { Meluangkan } \\
\text { waktumu }\end{array}$ & -2 & \\
\hline & & & $\begin{array}{l}\text { Mengisi } \\
\text { hidupmu }\end{array}$ & هـ & \\
\hline
\end{tabular}


الخطأ في هذا السؤال أنه لا يناسب الهدف، البديلة الصحيحة أكثر من واحدة، تكرار كلمة في البدائل والفقرة ليست جملة مفيدة،

ع) الفقرة ليست جملة مفيدة

\begin{tabular}{|c|c|c|c|}
\hline السؤال المقققة & نوع الأخطاء & 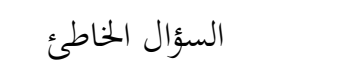 & رقم \\
\hline معنى "طول السهر" في الفقرة & - م- - البدائل غير & ما معنى "طول السهر" في & 9 \\
\hline السابقة هو .... & 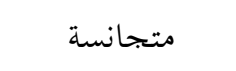 & الفقرة السابقة ؟ & \\
\hline
\end{tabular}

\begin{tabular}{|c|c|c|c|c|}
\hline bersahur & 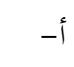 & - الفقرة ليست جملة & sahur & أ- \\
\hline bergadang & ب- & & bergadang & ب- \\
\hline menonton & ج- & معيده & menonton & ج- \\
\hline bergurau & -2 & & bergurau & -2 \\
\hline bekerja & ه & & bekerja & هـ \\
\hline
\end{tabular}

\begin{tabular}{|c|c|c|c|c|}
\hline \multicolumn{5}{|c|}{ الخطأ في هذا السؤال أ، البدائل غير متجانسة والفقرة ليست جملة مغيدة } \\
\hline السؤال المحققة & \multicolumn{2}{|l|}{ 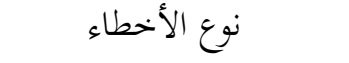 } & 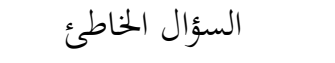 & رقم \\
\hline اقرأ الفقرة جيد|! & 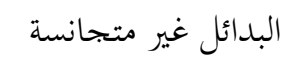 & - & اقرأ الفقرة جيدا! & 17 \\
\hline انظر إلى المريض، هو يشكو & البديلة الصحيحة البحة & - & \multicolumn{2}{|l|}{ انظر إلى المريض، هو } \\
\hline بالم شديد، عنده ألم شديد في & أكثر من واحدة & & \multicolumn{2}{|l|}{ يشكو بالم شديد، عنده } \\
\hline رأسه وفي معدتي. ويشعر بهذا & السؤال غير محدد & - & \multicolumn{2}{|l|}{ ألم شديد في رأسه وفي } \\
\hline الألم منذ ثلاثة أيام، وقد تناول & 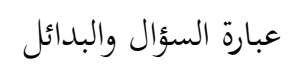 & - & \multicolumn{2}{|l|}{ معدتي. ويشعر هذا الألم } \\
\hline بعض الأقراص ولم تنفع. فذهب & 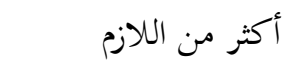 & & \multicolumn{2}{|l|}{ منذ ثلاثة أيام، وقد تناول } \\
\hline إلى عيادة الطبيب. & تكرار كلمة في البدائل & - & \multicolumn{2}{|l|}{ بعض الأقراص ولم تنفع. } \\
\hline الفعل المضارع في الفقرة السابقة & ت توزيع البدائل غير & - & \multicolumn{2}{|l|}{ فذهب إلى عيادة الطبيب. } \\
\hline هو (... & 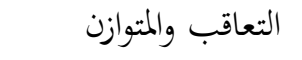 & & \\
\hline أ- أ- يشكو & 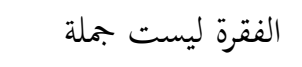 & - & \multicolumn{2}{|l|}{ الفعلان المضارعان في } \\
\hline ب- اب ذهب & 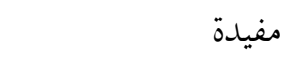 & & \multicolumn{2}{|l|}{ الفقرة السابقة ! } \\
\hline 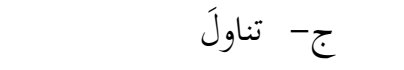 & & & \multicolumn{2}{|l|}{ أ- يشكو - انظر } \\
\hline د- انظر & & & \multicolumn{2}{|l|}{ ب- ذهب - تناولَ } \\
\hline هـ- عيادة & & & \multicolumn{2}{|l|}{ ج- عيادة - يشكو } \\
\hline & & & \multicolumn{2}{|l|}{ د- شديد - يشعر } \\
\hline & & & \multicolumn{2}{|l|}{ هـ- تشعر - تنفع } \\
\hline
\end{tabular}


الخطأ في هذا السؤال هو البدائل غير متجانسة، البديلة الصحيحة أكثر من واحدة، السؤال غير محدد، عبارة السؤال

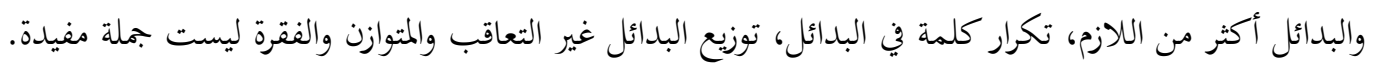
(7) البدائل غير متجانسة

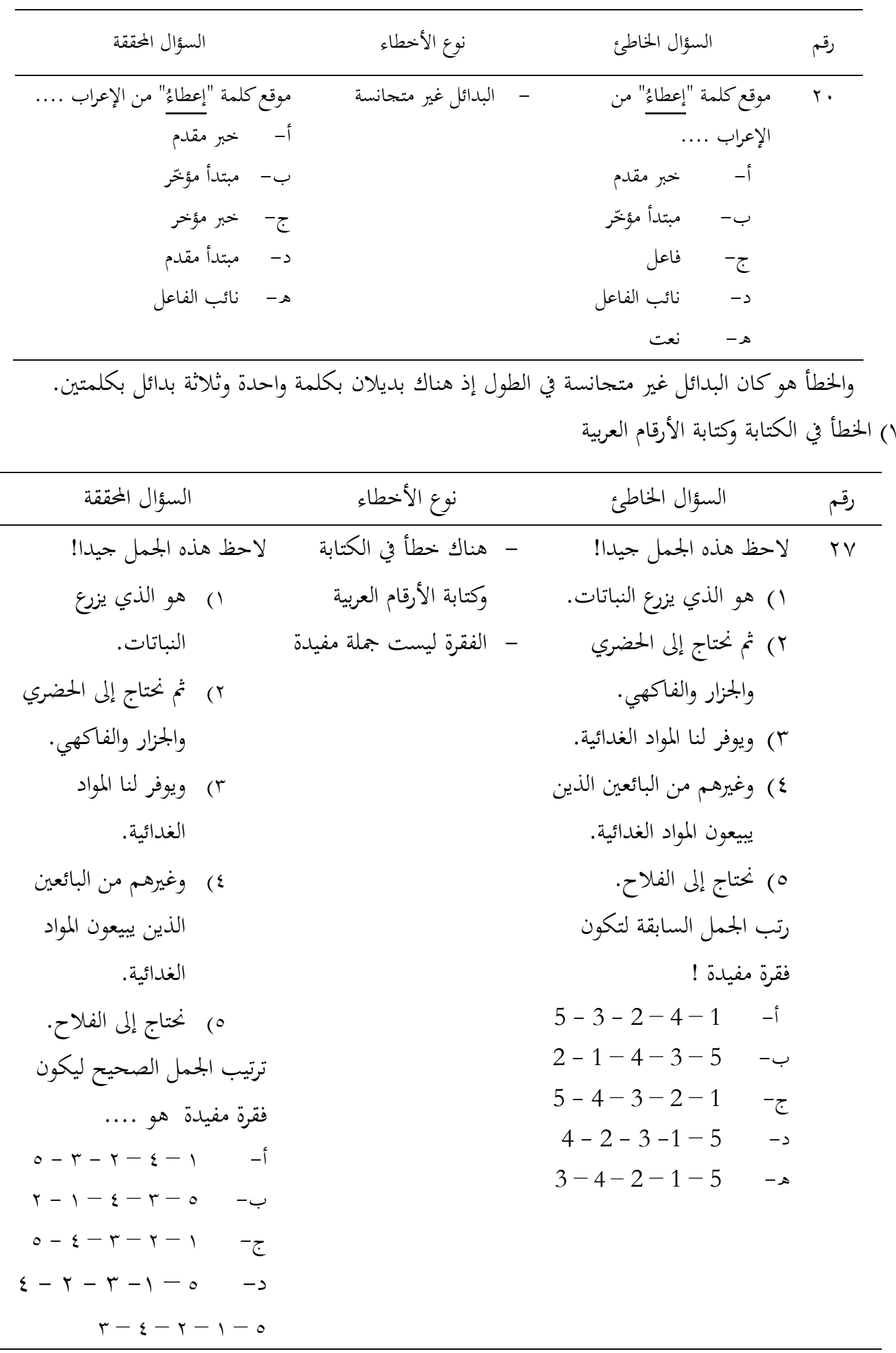


هناك خطأ في الكتابة وكتابة الأرقام العربية والفقرة ليست جملة مفيدة. كان في السؤال الحقيق يكتب أ. 1- 4 - 2 -3 - 5، إذ الصحيح هو كان مكتوبا باللغة العربية. م) البديلة الصحيحة أكثر من واحد

\begin{tabular}{|c|c|c|c|c|c|c|}
\hline \multirow{2}{*}{\multicolumn{2}{|c|}{ وقد ... على المسلمين أن يتفكروا في المعقة }} & \multicolumn{2}{|c|}{ نوع الأخطاء } & \multicolumn{2}{|l|}{ السؤال الخاطئ } & \multirow{2}{*}{ رقم } \\
\hline & & البدائل غير متحانسة & - & على المسلمين أن يتفكروا في & 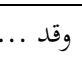 & \\
\hline \multicolumn{2}{|c|}{ أحوال الكون. } & البديلة الصحيحة & - & \multicolumn{3}{|c|}{ أحوال الكون. } \\
\hline فرض & 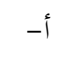 & أكثر من واحد & & فرض & 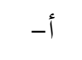 & \\
\hline فُرِض & ب- & البدائل أكثر من & - & 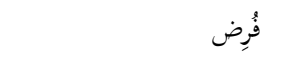 & 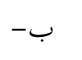 & \\
\hline افترض & ج- & الملازم & & فرضه & ج- & \\
\hline أفترض & -2 & الخطأ في كتابةالكسرة & - & فرّض & -2 & \\
\hline أفرض أف & $-\infty$ & & & فُرُّضض & $\rightarrow$ & \\
\hline
\end{tabular}

الخطأ في هذا السؤال هي البدائل غير متجانسة، البديلة الصحيحة أكثر من واحد، البدائل أكثر من اللازم والخطأ

في كتابة الكسرة.

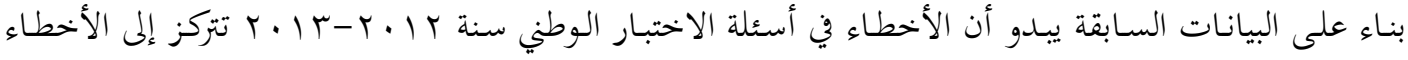

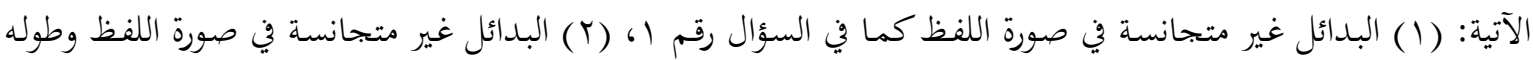
كما في السؤال رقم ץ، (r) السؤال لا يناسب الهدف، البديلة الصحيحة أكثر من واحدةة، تكرار كلمة في البدائل والفقرة

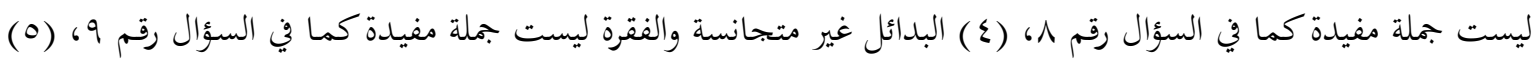

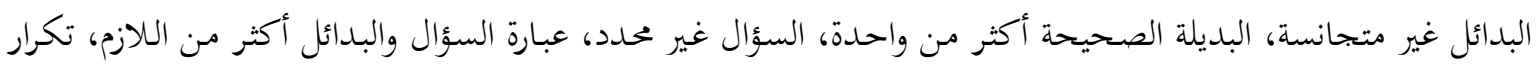

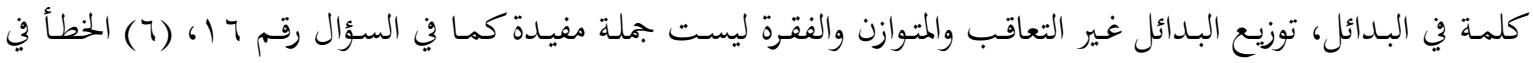

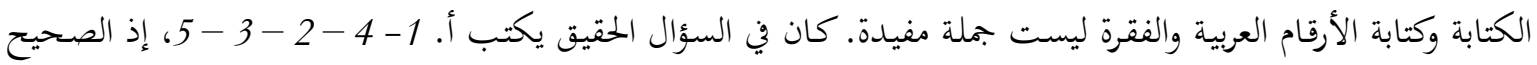

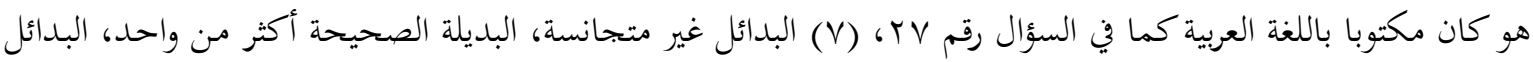

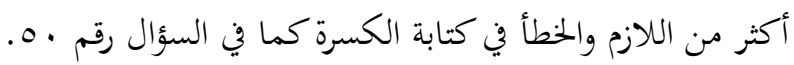

بعد تقديم التحليلات للبييانات كيفية وكمية يبدو أن الاختبار النهائي على المستوى الوطني مازال فيه عيوب من حيث الكيف وما زال محتاجا إلى التحسين طبقا بتقرير المشكلات، ولات سيما من ناحية مستوى نوعية الاختبار كيفيا مازال

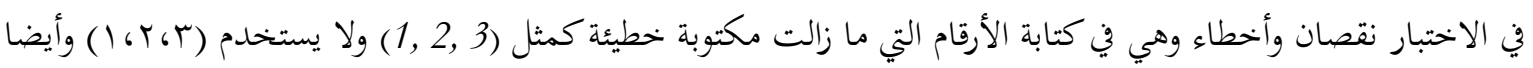

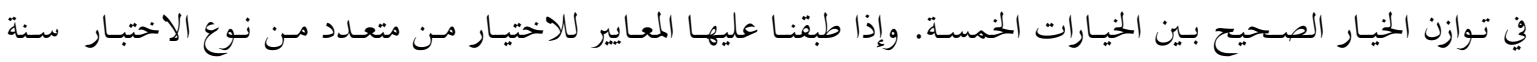

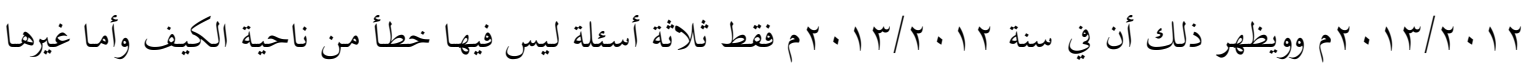

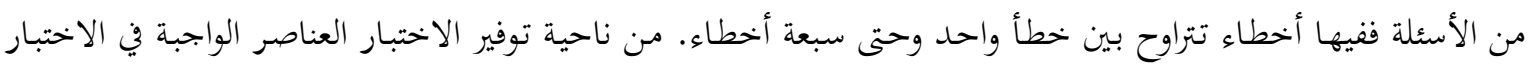

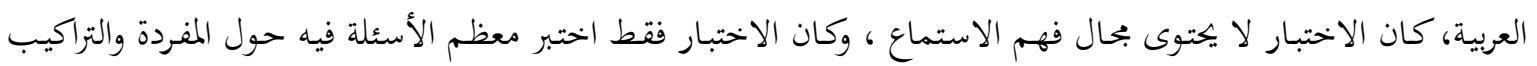

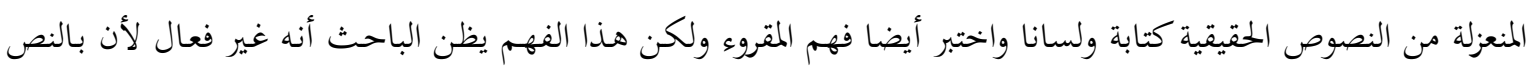

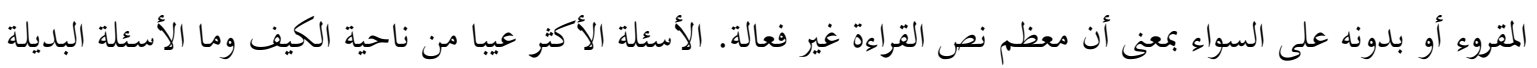



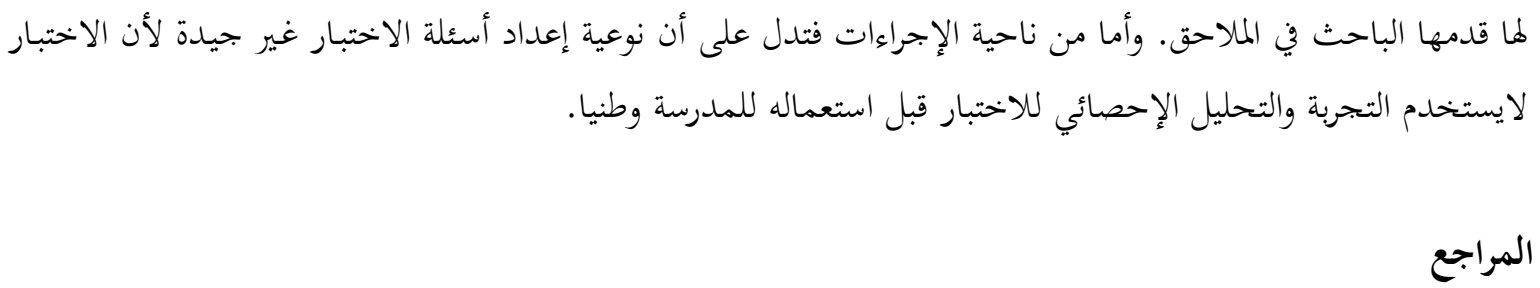

Arifin, Zainal, (2012). Evaluasi pembelajaran, cet. ke. 4. Bandung: Remaja Rosdaarya.

Athanasao, James A. and Iasonas Lamprinaou, (2002). A tacher's guide to assessment, Australia: Social Science Press (SSP).

B. Uno, Hamzah dan Satria Koni, (2012). Assessment pembelajaran; salah satu bagian penting dari pelaksanaan pembelajaran yang tidak dapat diabaikan adalah pelaksanaan penilaian, Jakarta: Bumi Aksara

Dandri, Iqbal Zaenul Arifin, Diräsat muqāranah li atsar istikebdàm namüdzaj al-qarārät al-muta'addidah (CIPP) wa namüdzaj ma'āyìr al-adā li taqwìm barāmij al-maubūbät wa shan'i al-qarārāt. Warqah ilmiyyah muqaddamah li al-mu'tamar al-'ilmy al-iqlīmy li al-mauhūbah al-ladzy ta'qiduhu Muassasat al-Malik Abd al-Azīz wa rijāluhu li ri'āyat al-mauhūbīn bi Madinat Jiddah bi al-Mamlakah al-'Arabiyyah as-Su'ūdiyyah on 29 April 2013.

Dewidri, Raja Wahid. (2008). Al-Bahtsu al-ilmy: asäsiyyätubu an-nadzariyyah wa mumārasatubu alilmiyah. Bairut: Dār al-Fikri al-Mu'āshir wa Dār al-Fikri.

Djiwandono, M. Soenardi, (2008). Tes bahasa: pengajar bagi pengajar bahasa, Jakarta: Indeks

Gronlund, Norman E, (1996). Constructing achievement tests, London: Pritice-Hall.

Hakīm, Abd al-Hamīd bin al-Majīd bin Abd al-Hamīd. Al-Ikbtibärät wa l-qiyās wa at-taqwìm. AlMamlakah al-'Arabiyyah as-Su'ūdiyyah. Wazārat at-Ta'līm al-'Āly, Kulliyat al-Mu'allimīn bi Makkah al-Mukarramah, Markazu Khidmat al-Mujtama' wa at-Ta'limm al-Mustamir, Muharram 1425H, Page 24-25. In uqu.edu.sa., down loaded on Monday, 30 March 2013.

Keputusan Direktur Jenderal Pendidikan Islam, Nomor: 21 tahun 2013 tentang Ketentuan pelaksanaan ujian akhir madrasah berstandar nasional pendidikan agama islam dan bahasa arab tingkat madrasah ibtidaiyah, madrasah tsanawiyah, dan madrasah aliyah tahun pelajaran 2012/2013.

Muhammad, Abdul Khaliq. (1989). Ikhtibārāt al-lughah. As-Su'ūdiyyah: Imādat Syu'ūn alMaktabāt - Jāmi'at al-Malik Su'ūd.

Patera, Jos Daniel, (1986). Linguistik edukasional, Jakarta: Erlangga.

Peraturan Menteri Pendidikan Nasional No 20 tahun 2007 tentang Standar Penilaian Pendidikan.

Popham, W. James, (1994). Calssroom assessment: what teachers need to know, Boston-LondonToronto-Sydney-Tokyo-Singapore: Allyn and Bacon.

Purwanto, M. Ngalim, (2004). Prisnsip-prinsip dan teknik evaluasi pengajaran, cet. 12. Bandung: Remaja Rosdakarya.

Sudjana, Nana, (2009). Penilaian basil proses belajar mengajar, cet. ke-14. Bandung: Remaja Rosda Karya, 2009.

Sukardi, H. M., (2011). Evaluasi pendidikan prinsip dan operasionalnya, Yogyakata: Bumi Aksara.

Surapranata, Sumarna, (2005). Analisis validitas, reliabilitas dan interpretasi hasil tes, Bandung, Remaja Rosdakarya.

Surapranata, Sumarna, (2005). Panduan penilaian tes tertulis implementasi kurikulum 2004, cet. ke-2. Bandung, Remaja Rosdakarya.

Wirawan, (2008). Pengantar evaluasi program, Jakarta: Program Pascasarjana Universitas Muhammadiyah Prof. Dr. HAMKA.

Yunus, Fathi Ali dan Muhammad Abdul Rauf. (2003). Al-Marja' fì ta'lim al-'Arabiyyah li 'l-ajänib: min an-nadrariyyat ila at-tathbiq. Al-Qahirah: Maktabat Wahby 